\title{
First Report of Parasaissetia nigra in Khaya ivorensis Seedlings in Brazil
}

\author{
Leonardo Leite Fialho Júnior ${ }^{1}$ (D), Isabel Carolina de Lima Santos ${ }^{1}$ (D), \\ Alexandre dos Santos ${ }^{1}$ \\ ${ }^{1}$ Laboratório de Fitossanidade - FitLab, Instituto Federal de Mato Grosso - IFMT, Cáceres/MT, Brasil
}

\begin{abstract}
The objective of this research is to report the occurrence of the nigra scale Parasaissetia nigra (Nietner, 1861) (Hemiptera: Coccidae) in mahogany (Khaya ivorensis) seedlings in a forest nursery in Mato Grosso state. In September 2017, the infestation was detected on the leaves and branches of the plants, causing injury and the death of the apical meristem and leaf curling symptoms. It was verified the symbiosis of $P$. nigra with ants, due to the sugary exudate. The chemical control was performed with insecticidal syrup and the proposed method was effective. This was the first reported occurrence of $P$. nigra on African mahogany in Brazil.
\end{abstract}

Keywords: african mahogany, nigra scale, forestry entomology. 
The species Khaya ivorensis, belonging to the Meliaceae botanical family comes from regions of West Africa, where it occurs naturally in Côte d'Ivoire, Ghana, Angola, Togo, Benin, Nigeria and Cameroon (Lemmens, 2008). This tree species is commonly called African mahogany, presents great economic importance, having its plantation explored commercially in the countries of natural occurrence and in Asian and South American countries (Moura et al., 2017).

It is a large tree, with average height ranging from 40 to 50 meters and diameter at 1.30 meters from the ground level can reach up to $200 \mathrm{~cm}$. The stem is rectilinear, free of branches up to $30 \mathrm{~m}$ in height, with thick reddish-brown rhytidome and bitter taste (Nikles et al., 2008). The leaves are pinnate, with four to seven pairs of leaflets, their flowers are small and white, and the fruits are of capsules dehiscent type (Dipelet et al., 2017).

In Brazil, the introduction of African mahogany occurred in the decade of 1970, in the Pará state, through seeds from Côte d'Ivoire (Ribeiro et al., 2017). Currently, the distribution of plantations occurs in all over the country (Sartoretto \& Rossi, 2014).

K. ivorensis present great resistance to Hypsiphyla grandella (Zeller, 1848) (Lepidoptera: Pyralidae), knonw as Mahogany woodborer (Verzignassi et al., 2009). This insect, in larval phase, injures and kills the terminal bud, breaking the apical dominance, damaging the stem growth (Brunck \& Mallet, 1993). It guaranteed to this species a competitive advantage against Swietenia macrophylla, the Brazilian mahogany. However, according to Zanetti et al. (2017), H. grandella was attack a commercial plantation in Brazil, indicating that African mahogany is not free from the injury of this pest. Other insect attacks have also been reported (Ofori et al., 2007; Ong et al., 2014).

The scales are insects that feed on a wide variety of plant species, being abundant in forest stands and causing damages to attacked crops (Culik et al., 2013; Abdelkader, 2016). The nigra scale Parasaissetia nigra (Nietner, 1861) (Hemiptera: Coccidae) is a polyphagous species that attack different plant species of agricultural importance, highlighting citrus, coffee and cotton (Myartseva et al., 2014). There are no records of this species attack on Khaya ivorensis plants, or records of chemical control techniques for scale insects to African mahogany in the Brazilian Ministry of Agriculture, Livestock and Food Supply (Brasil, 2018).

In this context, this work aimed to report the first occurrence of Parasaissetia nigra (Nietner, 1861) (Hemiptera: Coccidae) on seedlings of Khaya ivorensis, describe the injuries caused and propose an experimental chemical control for this insect.

In September 2017 the infestation by scale was detected in Khaya ivorensis individuals in the forest nursery of the Instituto Federal de Educação, Ciência e Tecnologia de Mato Grosso (IFMT), Campus Cáceres, in the municipality of Cáceres ( $57^{\circ} 40^{\prime} 51^{\prime \prime} \mathrm{W}, 16^{\circ} 11^{\prime} 42^{\prime \prime} \mathrm{S}$ and altitude of $117 \mathrm{~m}$ ), Mato Grosso state, Brazil. The injuries caused on the mahogany seedlings were characterized and photographed. Scale specimens were collected in the plants and preserved in 70\% alcohol. Subsequently, they were sent to the Laboratório de Fitossanidade of the IFMT Campus Cáceres, Mato Grosso state, Brazil, separated in samples and sent to specialist for identification. After identification, voucher specimens were deposited in the Forest Protection Collection of the Laboratório de Fitossanidade of the IFMT - Campus Cáceres.

The specimens were identified as Parasaissetia nigra (Nietner, 1861) (Hemiptera: Coccidae), as shown in Figure 1.

This species of scale presents as biological aspects dark brown color in the young phase and bright black color in the adult phase, oval-elongated shape, with slightly convex back and ventral region (Abd al-Rasul \& Al-Mallu, 2014). Adult females can measure about 3-5 mm, depending on the host species, and their reproduction is parthenogenic (Ben-Dov, 1978).

The attack on Khaya ivorensis occurred in the vegetative organs twigs, leaves, and branches. The injuries denoted were the death of the apical bud and leaf corrugation (Figure 2).

P. nigra feeds on the plant by suction on the phloem, reducing the nutrients and consequently affecting its development (Mau \& Kessing, 2007). It was verified that this species presents symbiosis with unidentified ants species, these being observed together with the scale insects in all the infested plants (Figure 3 ). This interaction occurs because $P$. nigra releases an exudate, which reduces the photosynthetic area of the host and facilitates the development of saprophytic fungi, 


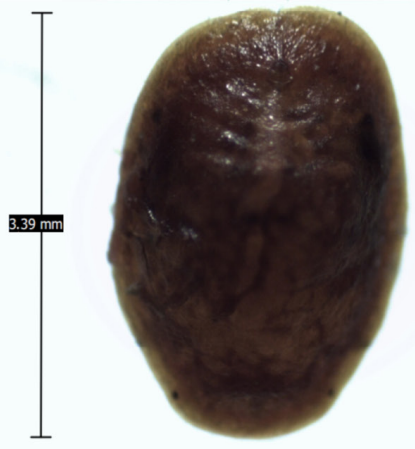

a

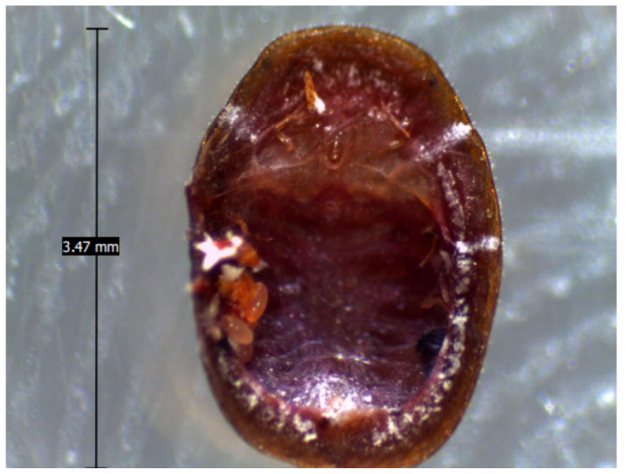

b

Figure 1. Nigra scale Parasaissetia nigra (Nietner, 1861) (Hemiptera: Coccidae); (a) dorsal region; (b) ventral region.
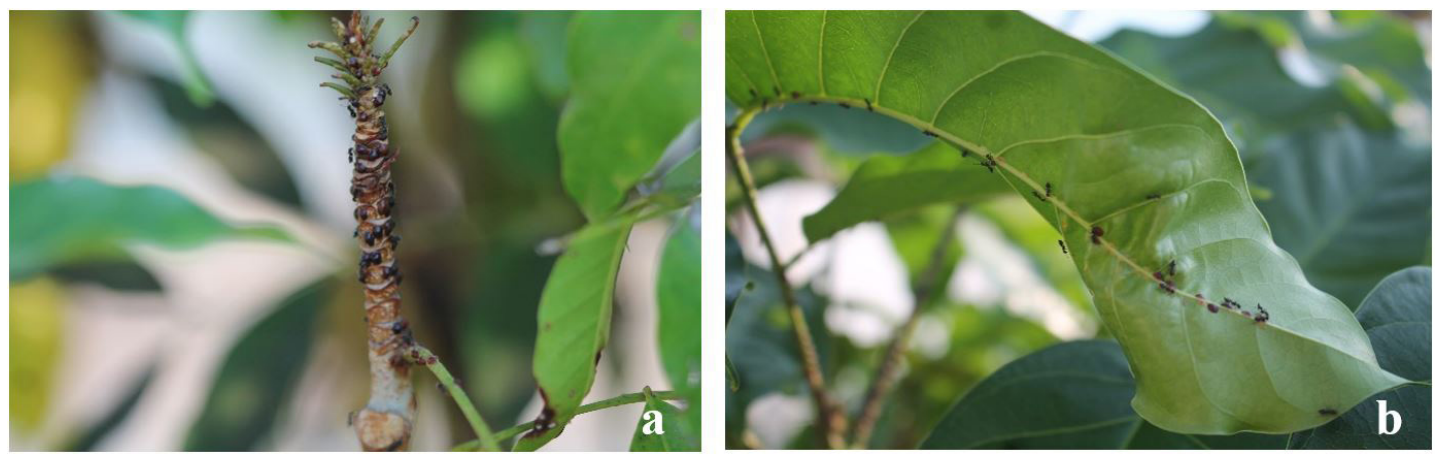

Figure 2. (a) Injury caused by Parasaissetia nigra to the apical bud of K. ivorensis, causing death; (b) K. ivorensis leaf corrugation, caused by the attack of $P$. nigra.
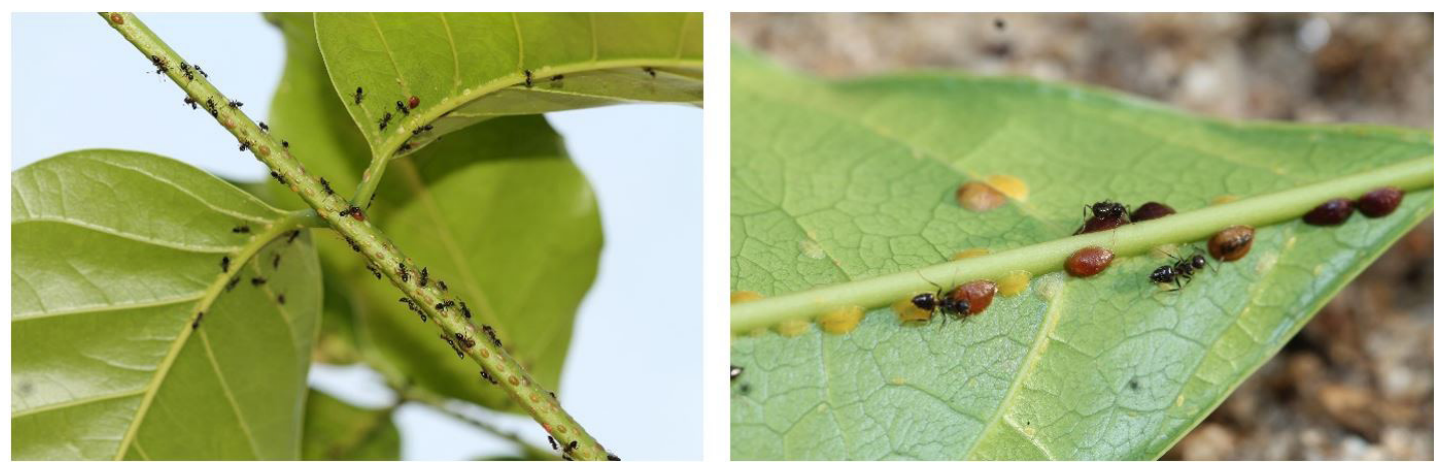

Figure 3. Symbiosis presented by $P$. nigra with unidentified ants.

causing fumagine (EPPO, 2002), not observed in the present work.

There is no registered product for the control of P. nigra in African mahogany (Khaya ivorensis) plants, however, an experimental chemical control was performed with an insecticidal syrup spray consisting of $0.8 \mathrm{~mL} / \mathrm{L}$ of agricultural mineral oil (Paraffin and aromatic hydrocarbons mixture from petroleum distillation and polysorbate 80 emulsifier at $0.005 \%$ ) and $6 \mathrm{ml} / \mathrm{L}$ of deltamethrin at 2.5\% (Pyrethroid chemical group) in distillated water. The plants were sprayed with this syrup to the point of drainage and monitored for a period of seven days in order, to evaluate the mortality of $P$. nigra. The proposed method was widely effective, 
showing $100 \%$ of efficiency in the mortality of this pest in the time analyzed. Chemical control using agricultural mineral oil and deltamethrin is commonly used for several scales species (Garcia \& Cim, 1997; Felippe et al., 2005; Brito et al., 2008).

\section{ACKNOWLEDGEMENTS}

To Ernesto Prado and Lenira Viana Costa Santa-Cecília of EPAMIG Sul/ECOCENTRO in Lavras, Minas Gerais State and Ana Lucia Benfatti Gonzalez Peronti of UNESP in Jaboticabal, São Paulo State for species identification. To "Pró-Reitoria de Pesquisa, Pós-graduação e Inovação (PROPES) do Instituto Federal de Educação, Ciência e Tecnologia de Mato Grosso (IFMT, Brasil)” for supporting our research.

\section{SUBMISSION STATUS}

Received: 29 mar., 2018

Accepted: 11 july, 2018

\section{CORRESPONDENCE TO}

\section{Alexandre dos Santos}

Laboratório de Fitossanidade - FitLab, Instituto Federal de Mato Grosso - IFMT, Av. dos Ramires, s/n, Distrito Industrial, CEP 78200-000, Cáceres, MT, Brasil

e-mail: alexandre.santos@cas.ifmt.edu.br

\section{REFERENCES}

Abdelkader A. Study of the level of infestation by the white cochineal Parlatoria blanchardi Targ.1868 (Homoptera, Diaspididae) on the principal varieties of date palm in the valley of Oued Righ (South East of Algeria). Journal of Entomology and Zoology Studies 2016; 4(6): 653-656.

Abd al-Rasul MS, Al-Mallu IM. First record of nigra scale, Parasaissetia nigra (Nietner, 1861) (Hemiptera; Coccidae) as a pest of fig trees in Iraq. Bulletin of the Iraq Natural History Museum 2014; 14(2): 171-178.

Ben-Dov Y. Taxonomy of the nigra scale, Parasaissetia nigra (Nietner) (Homoptera: Coccoidea: Coccidae), with observations on mass rearing and parasites of an Israeli strain. Phytoparasitica 1978; 6(3): 115-127. http://dx.doi. org/10.1007/BF02981211.

Brasil. Ministério da Agricultura, Pecuária e Abastecimento. Agrofit: sistema de agrotóxicos fitossanitários [online]. Brasília;
2018 [cited 2018 Mar 20]. Available from: http://agrofit. agricultura.gov.br/agrofit_cons/principal_agrofit_cons

Brito CH, Lopes EB, Albuquerque IC, Batista JL. Avaliação de produtos alternativos e pesticidas no controle da cochonilha-do-carmim na Paraíba. Revista de Biologia e Ciências da Terra 2008; 8(2): 1-5.

Brunck F, Mallet B. Les problems phytosanitaires de l'acajou en CoteD'Ivorie. Bois et Forêts des Tropiques 1993; 237(3): 9-29.

Culik MP, Martins DS, Zanuncio JS Jr, Fornazier MJ, Ventura JA, Peronti ALBG et al. The invasive hibiscus mealybug Maconellicoccus hirsutus (Hemiptera: Pseudococcidae) and its recent range expansion in Brazil. The Florida Entomologist 2013; 96(2): 638-640. http:// dx.doi.org/10.1653/024.096.0234.

Dipelet UGB, Florence J, Doumenge C, Loumeto JJ, McKey D. Khayae (Meliaceae) specierum Nomenclator. Adansonia 2017; 39(1): 15-30. http://dx.doi.org/10.5252/a2017n1a2.

European and Mediterranean Plant Protection Organization - EPPO. Diagnostic protocols for regulated pests. Bulletin OEPP/EPPO 2002; 32(1): 293-298.

Felippe MR, Garbim LF, Coelho JHC, Ximenes NL, Sanchez AL, Yamamoto PT. Controle químico da cochonilha ortézia em citros. Laranja 2005; 26(2): 251-264.

Garcia FRM, Cim JD. Avaliação da eficiência de inseticidas no controle de Unaspis citri (Comstock, 1883) (Homoptera: Diaspididae). Uruguaiana 1997; 4(1): 10-15.

Lemmens RHMJ. Khaya ivorensis A. Chev. In: Louppe D, Oteng-Amoako AA, Brink M, editors. PROTA: plant resources of tropical Africa. Wageningen: University Fund Wageningen; 2008 [cited 2017 Oct 15]. Available from: http://www.prota4u.org/search.asp

Mau RFL, Kessing JLM. Parasaissetia nigra (Nietner). Hawaii: Crop Knowledge Master; 2007 [cited 2017 Nov 29]. Available from: http://www.extento.hawaii.edu/kbase/ crop/Type/p_nigra.htm

Moura RS, Souza KR, Souza DDS, Santana GM, Oliveira GMD, Venturoli F et al. Danos em Khaya ivorensis provocado por Trigona spinipes na savana brasileira. Acta Brasiliensis 2017; 1(1): 40-42. http://dx.doi.org/10.22571/ Actabra11201715.

Myartseva SN, Ruíz-Cancino E, Coronado-Blanco JM. Parasaissetia nigra (Hemiptera: Coccidae) and its parasitoids from the genus Coccophagus Hymenoptera: Aphelinidae), with description of a new species from Tamaulipas, México. The Florida Entomologist 2014; 97(3): 1015-1020. http:// dx.doi.org/10.1653/024.097.0302.

Nikles DG, Bevege D, Dickinson G, Griffiths M, Reilly DF, Lee D. Developing African mahogany (Khaya senegalensis) germplasm and its management for a sustainable forest plantation industry in northern Australia: progress and needs. Australian Forestry 2008; 71(1): 33-47. http://dx.doi. org/10.1080/00049158.2008.10676269. 
Ofori DA, Opuni-Frimpong E, Cobbinah JR. Provenance variation in Khaya species for growth and resistance to shoot borer Hypsipyla robusta. Forest Ecology and Management 2007; 242(2-3): 438-443. http://dx.doi. org/10.1016/j.foreco.2007.01.090.

Ong SP, Lee SS, Kirton LG. The Khaya ivorensis Bark Borer, Cossus Chloratus. Frim Technical Information 2014; 74: 1-4.

Ribeiro A, Ferraz-Filho AC, Scolforo JRS. O cultivo do Mogno Africano (Khaya spp.) e o crescimento da atividade no Brasil. Floresta e Ambiente 2017; 24(0): e00076814. http://dx.doi.org/10.1590/2179-8087.076814.
Sartoretto LM, Rossi E. Caracterização de três espécies florestais de importância econômica. Unoesc \& Ciência 2014; 5(2): 145-152.

Verzignassi JR, Poltronieri LS, Benchimol RL. Mancha-alvo em mogno-africano no Brasil. Summa Phytopathologica 2009; 35(1): 70-71. http://dx.doi.org/10.1590/S010054052009000100015.

Zanetti R, Abreu CS, Silveira SHP, Andrade ED. First report of Hypsipyla grandella (Lepidoptera: Pyralidae) on African mahogany Khaya ivorensis. Scientia Agrícola 2017; 74(6): 492-494. http://dx.doi.org/10.1590/1678992x-2016-0362. 